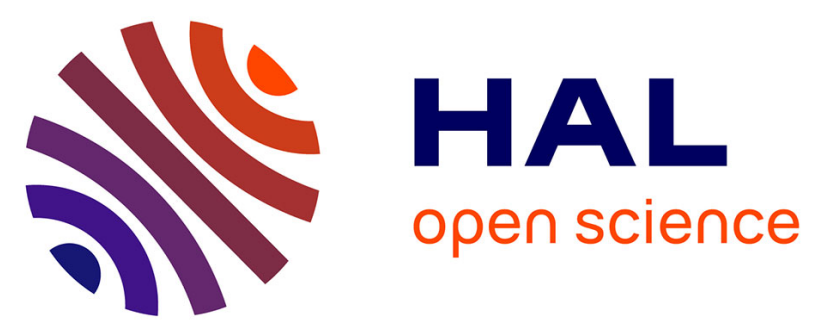

\title{
Stepwise Functionalization of N 2 at Mo: Nitrido to Imido to Amido - Factors Favoring Amine Elimination from the Amido Complex
}

\author{
Soukaina Bennaamane, Maria F Espada, Ikram Yagoub, Nathalie
}

Saffon-merceron, Noel Nebra, Marie Fustier-Boutignon, Eric Clot, Nicolas

Mézailles

\section{To cite this version:}

Soukaina Bennaamane, Maria F Espada, Ikram Yagoub, Nathalie Saffon-merceron, Noel Nebra, et al. Stepwise Functionalization of N 2 at Mo: Nitrido to Imido to Amido - Factors Favoring Amine Elimination from the Amido Complex. European Journal of Inorganic Chemistry, 2020, 2020 (15-16), pp.1499-1505. 10.1002/ejic.201901295 . hal-03012876

\section{HAL Id: hal-03012876 https://hal.science/hal-03012876}

Submitted on 27 Oct 2021

HAL is a multi-disciplinary open access archive for the deposit and dissemination of scientific research documents, whether they are published or not. The documents may come from teaching and research institutions in France or abroad, or from public or private research centers.
L'archive ouverte pluridisciplinaire HAL, est destinée au dépôt et à la diffusion de documents scientifiques de niveau recherche, publiés ou non, émanant des établissements d'enseignement et de recherche français ou étrangers, des laboratoires publics ou privés. 


\title{
Stepwise Functionalization of $\mathbf{N}_{2}$ at Mo: Nitrido to Imido to Amido. Factors Favoring Amine Elimination from the Amido Complex.
}

\author{
Soukaina Bennaamane, ${ }^{[a]}$ Maria F. Espada, ${ }^{[a]}$ Ikram Yagoub, ${ }^{[a]}$ Nathalie Saffon-Merceron, ${ }^{[b]}$ Noel \\ Nebra, ${ }^{[a]}$ Marie Fustier-Boutignon, ${ }^{[a]}$ Eric Clot, ${ }^{[c] *}$ Nicolas Mézailles ${ }^{[a] \star}$ \\ Dedication: In the memory of Prof. P. Le Floch.
}

\begin{abstract}
Functionalization of nitrido complex $\left[\left(\mathrm{P}^{\mathrm{Ph}} \mathrm{P}_{2}{ }^{\mathrm{Cy}}\right) \mathrm{Mo}(\mathrm{N})(\mathrm{I})\right]$ by a bis-silane in concentrated medium generates the hydrido-imido complex $\left[\left(\mathrm{P}^{\mathrm{Ph}} \mathrm{P}_{2}{ }^{\mathrm{Cy}}\right) \mathrm{Mo}(\mathrm{H})\left(=\mathrm{NSiMe}{ }_{2} \mathrm{CH}_{2} \mathrm{CH}_{2} \mathrm{SiMe}_{2} \mathrm{H}\right)(\mathrm{I})\right]$. Abstraction of the iodide by thallium salt TIX $\left(X=\mathrm{PF}_{6}\right.$, OTf) results in a second $\mathrm{N}-\mathrm{Si}$ bond formation and forms the bis-hydride amide complex $\left[\left(\mathrm{P}^{\mathrm{Ph}} \mathrm{P}_{2}{ }^{\mathrm{Cy}}\right) \mathrm{Mo}(\mathrm{H})_{2}\left(\mathrm{NSiMe}_{2} \mathrm{CH}_{2} \mathrm{CH}_{2} \mathrm{SiMe}_{2}\right)\right]^{+}$. An alternative synthesis relies on the abstraction of the iodide from the nitride complex $\left[\left(\mathrm{P}^{\mathrm{Ph}} \mathrm{P}_{2}{ }^{\mathrm{Cy}}\right) \mathrm{Mo}(\mathrm{N})(\mathrm{I})\right]$ to generate the corresponding cationic complex $\left[\left(\mathrm{P}^{\mathrm{Ph}} \mathrm{P}_{2}{ }^{\mathrm{Cy}}\right) \mathrm{Mo}(\mathrm{N})\right]^{+}$followed by addition of the bis-silane. Addition of $\mathrm{PMe}_{3}$ to the $\left[\left(\mathrm{P}^{\mathrm{Ph}} \mathrm{P}_{2}{ }^{\mathrm{Cy}}\right) \mathrm{Mo}(\mathrm{H})_{2}\left(\mathrm{NSiMe}_{2} \mathrm{CH}_{2} \mathrm{CH}_{2} \mathrm{SiMe}_{2}\right)\right]^{+}$complex liberates the silylamine and forms the $\mathrm{Mo}^{(\mathrm{II})}$ cationic complex $\left[\left(\mathrm{P}^{\mathrm{Ph}} \mathrm{P}_{2}{ }^{\mathrm{Cy}}\right) \mathrm{Mo}(\mathrm{H})\left(\mathrm{PMe}_{3}\right)\right]^{+}$. DFT calculations rationalizing the observed reactivity are presented.
\end{abstract}

$\mathrm{N}_{2}$ functionalization under mild conditions represents one of the biggest challenges for chemists as well as a major societal concern. ${ }^{[1-6]} \mathrm{N}_{2}$ to $\mathrm{NH}_{3}$ transformation involves a multistep process that forms six $\mathrm{N}-\mathrm{H}$ bonds and breaks the $\mathrm{N} \equiv \mathrm{N}$ bond. Several pathways can be envisioned to create and break these bonds. Nature uses protons and electrons in a stepwise formation of $\mathrm{N}-\mathrm{H}$ bond and reduction of the $\mathrm{N}-\mathrm{N}$ bond order. ${ }^{[7-}$ ${ }^{11]}$ In the Haber Bosch process, metal atoms of a heterogeneous catalyst provide the six electrons to split $\mathrm{N}_{2}$ in a first step, while the $\mathrm{NH}$ bonds are created in subsequent steps. ${ }^{[12-15]}$ The latter process is appealing since it uses a neutral molecule, $\mathrm{H}_{2}$, to provide simultaneously the functionalizing moiety and the electrons (stored in the $\mathrm{H}-\mathrm{H}$ bond). ${ }^{[16]}$ By design, it avoids the use of charged species $\left(\mathrm{H}^{+}\right.$and $\left.\mathrm{e}^{-}\right)$that can react together rather than form the desired $\mathrm{N}-\mathrm{H}$ bonds. Several molecular complexes have been shown to split $\mathrm{N}_{2}$ under mild conditions, ${ }^{[17-22]}$ opening functionalization pathways of $\mathrm{N}_{2}$ via the transition metal (TM) nitrido complex. Elegant transformations to nitrile derivatives were reported by Cummins (with Mo) and Schneider (with Re) upon the use of strong electrophiles to circumvent the low nucleophilic character of the nitride $\mathrm{N}$ in the high valent $\mathrm{Mo}^{(\mathrm{VII})}$ and $\operatorname{Re}^{(\mathrm{V})}$.23-27] $^{27}$

\footnotetext{
[a] Dr. M. F. Espada, S. Bennaamane, Dr. N. Nebra, Dr. M. FustierBoutignon, Dr. N. Mézailles

Laboratoire Hétérochimie Fondamentale et Appliquée

Université Paul Sabatier, CNRS

118 Route de Narbonne, 31062 Toulouse (France)

E-mail: mezailles@chimie.ups-tlse.fr

[b] Dr. N. Saffon-Merceron

Institut de Chimie de Toulouse ICT-FR2599

Université Paul Sabatier, CNRS

31062 Toulouse Cedex (France)

[c] Dr. E. Clot

ICGM, Univ. Montpellier, CNRS, ENSCM, Montpellier, France

E-mail: eric.clot@umontpellier.fr
}

We have recently shown that $\mathrm{Si}-\mathrm{Cl}, \mathrm{Si}-\mathrm{H}$ bonds as well as $\mathrm{B}-\mathrm{H}$ bonds react with the $\left(\mathrm{PP}_{2}\right) \mathrm{Mo}^{\mathrm{IV}}$-nitrido complex to generate the corresponding imido complexes in a very facile process (Scheme 1 top).$^{[28-30]}$ However, at this point, and it is a general feature of imido complexes of Mo, the nucleophilic character of the $\mathrm{N}$ is drastically reduced, which hampers further functionalization under mild conditions. We successfully circumvented this problem by using bis-silane in excess and heating. Indeed, double $\mathrm{Si}-\mathrm{H}$ bond functionalization of the $\mathrm{Mo} \equiv \mathrm{N}$ moiety was achieved, ${ }^{[29]}$ as well as amine decoordination from the Mo center. Alternatively, creation of a vacant coordination site at the Mo center of the boryl-imido complex allowed a second $\mathrm{B}-\mathrm{H}$ bond addition to occur at room temperature. The ensuing (bis-boryl)amido $\mathrm{Mo}^{(\mathrm{IV})}$ complex proved very reactive toward excess of $\mathrm{B}-\mathrm{H}$ substrate, which prevented its isolation in pure form. In fact, amido complexes synthesized by two subsequent functionalizations of a nitrido derivative are very rare. It was the goal of the present study to devise a facile entry to such complexes. To meet success, two strategies were employed, either from the nitrido or the imido cationic derivatives (Scheme 1 bottom). We also report studies directed toward $\mathrm{N}-\mathrm{H}$ bond formation from the amido derivative. Finally, DFT calculations rationalizing our experimental findings are presented in this article.

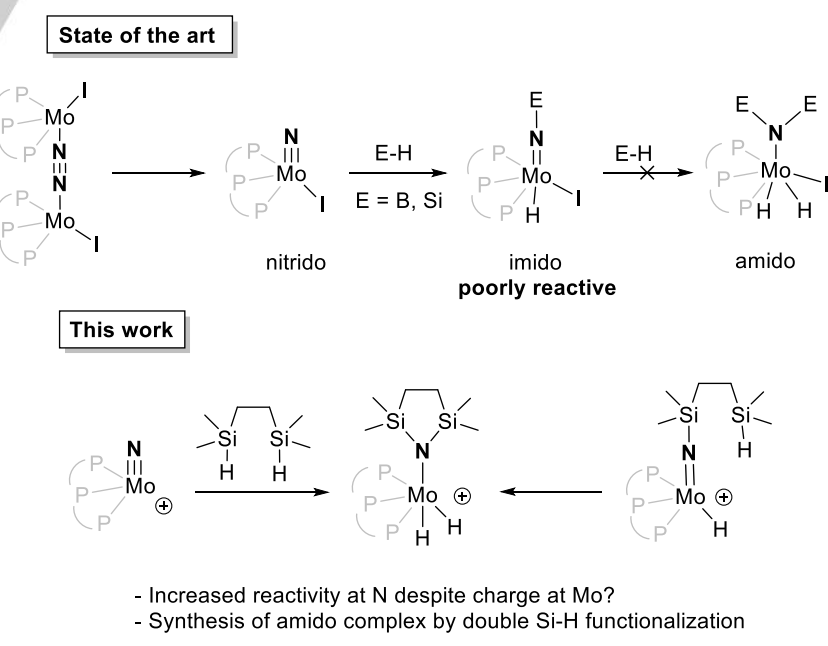

Scheme 1. Stepwise functionalization of $\mathrm{Mo}^{(\mathrm{IV})}$-nitrido complex and approaches to the cationic amido intermediate

The starting point of this study is the known nitrido complex $1\left[\left(\mathrm{P}^{\mathrm{Ph}} \mathrm{P}_{2}{ }^{\mathrm{Cy}}\right) \mathrm{Mo}(\mathrm{N})(\mathrm{I})\right]$, obtained via the $\mathrm{N}_{2}$ splitting between two Mo centers (Scheme 2). We have reported previously that complex 1 reacts with an excess (20 equiv.) of 
the bis-silane 2 to form the imido derivative 3 under mild conditions. ${ }^{[29]}$ We reinvestigated the addition reaction of $\mathrm{Si}-\mathrm{H}$ across the MoN bond under stoichiometric conditions. In fact, complex $\mathbf{3}$ can be synthesized with only one equiv. of bis-silane, yet more concentrated medium is required. Performing the reaction in deuterated solvent allowed its full NMR characterization. In particular, the two inequivalent $\mathrm{P}$ centers appear as two singlets at 91.3 and $108.8 \mathrm{ppm}$ (2:1 ratio) in the ${ }^{31} \mathrm{P}\left\{{ }^{1} \mathrm{H}\right\}$ spectrum, while the two different $\mathrm{Si}$ centers appear as singlets at -2.5 and -10.5 ppm for the $\mathrm{N}-\mathrm{Si}$ and $\mathrm{Si}-\mathrm{H}$ moieties respectively. It is interesting to note that the complex is not stable under vacuum, because of the facile reversible process. In that case, the low boiling point of the bis-silane favors the reformation of the nitrido complex 1 . When only half equiv. of bis-silane 2 was reacted with 1, few crystals slowly deposited from the solution over the course of 2 days, and a mixture of complex $\mathbf{3}$ and a novel complex, $\mathbf{4}$, in ca 8:2 ratio, together with remaining nitrido was observed in the supernatant (Figure S4). Complex 4 is characterized in the ${ }^{31} \mathrm{P}$ spectrum by two singlets at 91.0 and $109.5 \mathrm{ppm}$ (2:1 ratio), close to the chemical shifts of complex 3 which suggested the formation of another imido complex. Complex $\mathbf{4}$ was only observed in mixture with complex 3.. Note here that when an excess of bis-silane $\mathbf{2}$ is added to the mixture of 3 and 4 , a slow evolution to bissilylamine (Figure S5) and paramagnetic Mo(II) complex occurs. This is consistent with our previous observation of reactivity of complex 3 with bissilane.

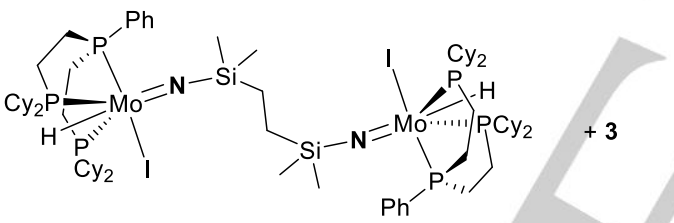

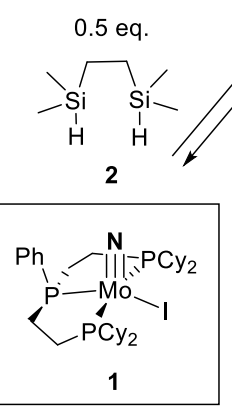

4

ratio $3 / 4: 8 / 2$ vacuum
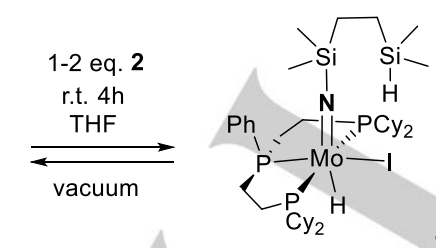

$98 \%(\mathrm{NMR})$
3

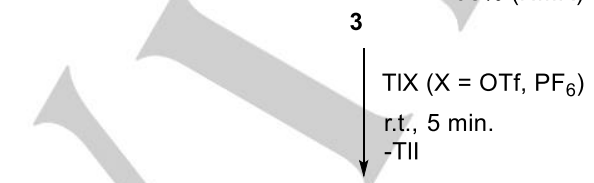

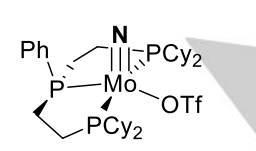

6-OTf
2 r.t. $5 \mathrm{~min}$

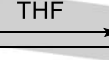

vacuum
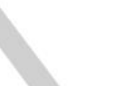

5-X $\quad X=O T f, P F_{6}$

Scheme 2. Stepwise functionalization of nitrido complex 1 by $\mathrm{Si}-\mathrm{H}$ bonds.
X-ray diffraction study proved the addition of the two $\mathrm{Si}-\mathrm{H}$ bonds to two nitrido complexes 1 to form complex 4 (Figure 1). Bond distances and angles are presented below the structure. The Mo-N bond distance of 1.787(3) $\AA$ is elongated compared to the Mo-N bond in complex 1 (1.656(2) $\AA$ ), as expected. All bond distances are similar to those measured in the related Moimido complex obtained by addition of $\mathrm{PhSiH}_{3}$ on complex $1{ }^{[29]}$

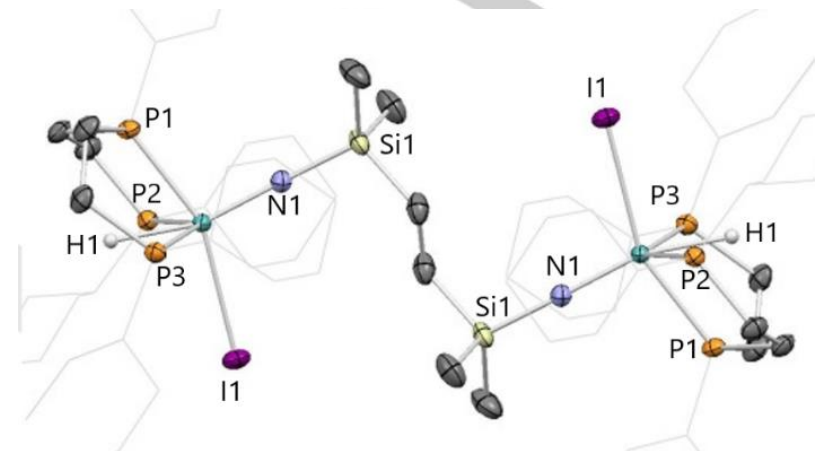

Figure 1. X-ray structure of complex 4: $50 \%$ thermal ellipsoids are shown Solvent molecule and hydrogen atoms, except for the hydride, have been omitted for clarity. Selected bond lengths $[\AA \AA]$ and angles $\left[{ }^{\circ}\right]$ : Mo1-N1 1.787(3), Mo1-P1 2.388(1), Mo1-P2 2.466(1), Mo1-P3 2.441(1), Mo1-I1 2.835(1), Mo1-H1 1.85(4), N1-Si1 1.755(3); N1-Mo1-P1 99.9(1), N1-Mo1-P3 113.0(1), P1-Mo1-P3 81.0(1), N1-Mo1-P2 115.9(1), P1-Mo1-P2 80.1(1), P3-Mo1-P2 129.8(1), N1-Mo1-I1 103.9(1), P1-Mo1-I1 156.2(1), P3-Mo1-I1 90.0(1), P2Mo1-I1 89.2(1), N1-Mo1-H1 162.7(11), P1-Mo1-H1 62.9(11), P3-Mo1-H1 64.1(11), P2-Mo1-H1 65.9(11), I1-Mo1-H1 93.3(11), Si1-N1-Mo1 175.5(2)

Pure complex 3 does not evolve at room temperature via a second $\mathrm{Si}-\mathrm{H}$ bond addition onto the $\mathrm{Mo}=\mathrm{N}$ moiety to form the amido-dihydride complex 5-I. However, when this complex was reacted with one equiv. of $\operatorname{TIX}\left(\mathrm{X}=\mathrm{OTf}\right.$ or $\left.\mathrm{PF}_{6}\right)$, an instantaneous reaction occurred to afford $\mathbf{5 - X}$, as evidenced by a color change from brown to dark purple and by the two signals at $116.0\left(\mathrm{~d}, J_{\mathrm{P}-\mathrm{P}}=5.2 \mathrm{~Hz}, 2 \mathrm{P}\right)$ and $133.3\left(\mathrm{t}, \mathrm{J}_{\mathrm{P}-\mathrm{P}}=5.2 \mathrm{~Hz}, 1 \mathrm{P}\right)$ ppm in the ${ }^{31} \mathrm{P}$ NMR spectrum. Complex $\mathbf{5 - X}$ was isolated in very good yield $(80 \%)$ and fully characterized by multinuclear NMR spectroscopy. In particular, a single signal for the two hydrides was observed at $-16.7 \mathrm{ppm}$ in ${ }^{1} \mathrm{H}$ NMR as a broadened pseudoquartet $\left(J_{\mathrm{HP}}=48.2 \mathrm{~Hz}\right)$, for apparent equivalent $\mathrm{H}$ centers. In an attempt to slow down the process of fast position exchange of the two hydrides, the spectrum was also recorded at $-80^{\circ} \mathrm{C}$. At that temperature, the signal sharpened yet remained a pseudoquartet proving a low energy process for hydride interconversion. $A T_{1, \min }$ of $135 \mathrm{~ms}$ was measured for the hydride signal, which is consistent with complex $\mathbf{5 - X}$ to feature two hydride ligands rather than a dihydrogen ligand. ${ }^{[31,32]}$ The complex is also characterized by two singlets in the ${ }^{29} \mathrm{Si}\left\{{ }^{1} \mathrm{H}\right\}$ spectrum at 13.6 and $14.7 \mathrm{ppm}$, corresponding to the two $\mathrm{Si}$ centers with different chemical environment. Importantly, the signal for $\mathrm{Si}-\mathrm{H}$ bond in complex 3 found at $-10.2 \mathrm{ppm}$ is now absent, also proving the second $\mathrm{N}-\mathrm{Si}$ bond formation.

Complex $\mathbf{5 - X}$ is stable at room temperature for extended periods, and even at $80^{\circ} \mathrm{C}$ for several hours but degrades upon prolonged heating. This observation points to difficult reductive elimination of the bis-silylamine $\mathbf{8}$ along with the corresponding 
(PPP)Mo ${ }^{(I I)}(\mathrm{H})^{+}$complex, which was rationalized by DFT calculations (vide infra).

In light of the facile second $\mathrm{Si}-\mathrm{H}$ bond formation upon halide abstraction, the reactivity of the cationic nitrido complex toward the bis-silane 2 was envisaged. Abstraction of ${ }^{-}$from complex 1 with TIOTf proved also very facile and efficient. Indeed, a sharp color change from dark orange to dark green could be observed instantaneously. Isolation of complex 6-OTf in $85 \%$ yield was achieved after filtration of the insoluble TII salts and drying. Quite surprisingly, the chemical shifts in the ${ }^{31} \mathrm{P}\left\{{ }^{1} \mathrm{H}\right\} \mathrm{NMR}$ spectrum are almost identical to those of complex 1 . The ${ }^{19} \mathrm{~F}$ spectrum nonetheless proved the OTf moiety to be present in the complex. Reaction of 6-OTf with one equivalent of the bissilane 2 proved almost instantaneous, leading quantitatively by ${ }^{31} \mathrm{P}$ NMR to complex 5-OTf. It is interesting to note that a solution of complex 5-OTf put under vacuum evolves back to complex 6-OTf, by evaporation of the low boiling point bis-silane 2. This reactivity proves the reversible character of the double $1,2 \mathrm{Si}-\mathrm{H}$ bond addition across the $\mathrm{Mo} \equiv \mathrm{N}$ bond.

Conditions to favor $\mathrm{N}-\mathrm{H}$ bond formation via reductive elimination and thus liberation of the amine were then sought.

We have shown previously that an in situ generated (bisboryl)amido-dihydride cationic complex does react at room temperature with $\mathrm{PinBH}$ to form a mixture of (BPin) ${ }_{3} \mathrm{~N}$ and (BPin $)_{2} \mathrm{NH}$ together with the $\left(\mathrm{PP}_{2}\right) \mathrm{Mo}(\mathrm{H})_{3}{ }^{+}$complex. ${ }^{[30]}$ We thus hoped that complex $\mathbf{5}-\mathbf{P F}_{6}$ would react with $\mathrm{PinBH}$ to form the corresponding boryl-(bis-silyl)amine, which was disapointingly not observed. However polymerization of THF was observed after several hours of reaction which we have previously observed when (PPP) Mo $(\mathrm{H})_{3}{ }^{+}$is formed.

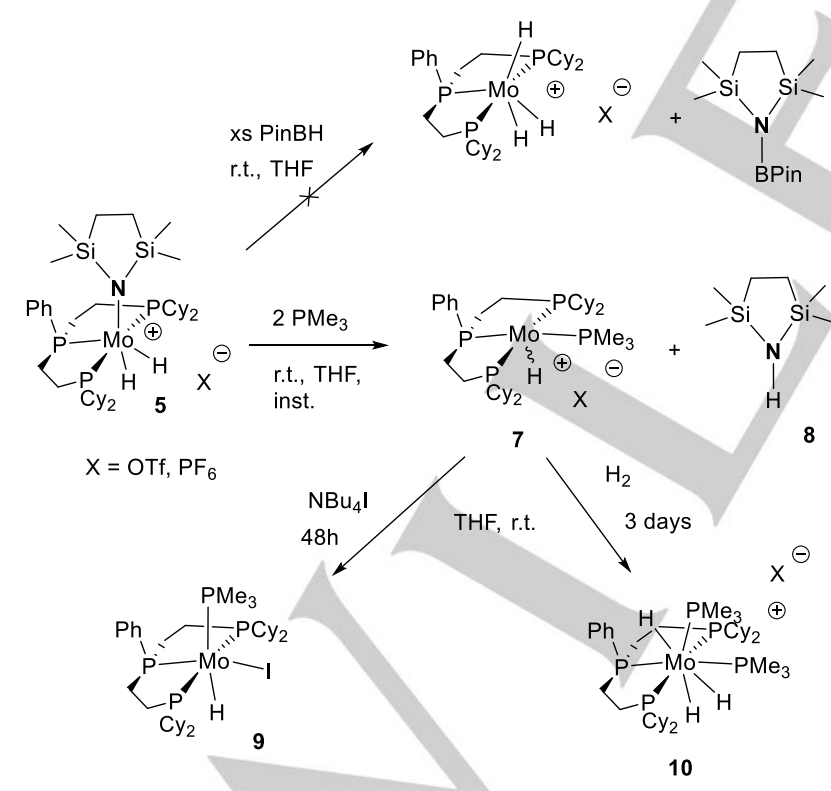

Scheme 3. Reactivity of complex 5-X

A distinct strategy was then envisioned relying on the addition of $\mathrm{PMe}_{3}$, a small strongly donating $2 \mathrm{e}^{-}$ligand in order to stabilize the coordinatively unsaturated (PPP)Mo"-fragment resulting from the reductive elimination of the cyclic (bissilyl)amine $\mathbf{8}$ from 5-X. Pleasingly, upon addition of two equiv. of $\mathrm{PMe}_{3}$ to a solution of complex 5-X an instantaneous reaction was observed, indicated by a color change from purple to dark green. The ${ }^{31} \mathrm{P}\left\{{ }^{1} \mathrm{H}\right\}$ NMR spectrum of the crude mixture revealed the formation of a new complex, in addition to free $\mathrm{PMe}_{3}$ and a very minor, unknown species (Fig S10, ESI). Integration of the signals as well as coupling pattern for complex $\mathbf{7 - X}\left(\mathrm{AM}_{2} \mathrm{X}\right.$ spin system) proved the coordination of a single $\mathrm{PMe}_{3}$ to the cationic Mo center. Indeed, the ${ }^{31} P\left\{{ }^{1} H\right\}$ NMR spectrum showed a very characteristic set of multiplets at $111.0 \mathrm{ppm}\left(\mathrm{d},{ }^{2} J_{\mathrm{P}-\mathrm{P}}=61.0 \mathrm{~Hz}\right.$, $\left.\mathrm{P}^{\mathrm{Ph}}\right), 89.6\left(\mathrm{~d},{ }^{2} J_{\mathrm{P}-\mathrm{P}}=18.8 \mathrm{~Hz}, \mathrm{P}^{\mathrm{Cy} 2}\right)$, and $-7.3\left(\mathrm{dt},{ }^{3} J_{\mathrm{P}-\mathrm{P}}=18.4 \mathrm{~Hz}\right.$, $\left.61.2 \mathrm{~Hz}, \mathrm{PMe}_{3}\right)$. The ${ }^{1} \mathrm{H}$ NMR spectrum presents a highly coupled signal centered at $-7.1 \mathrm{ppm}$ for a single hydride (Fig. 3 and ESI). Selective decoupling sequences with the three different $P$ centers allowed isolation of the individual ${ }^{2} J_{P-H}$ coupling constants (ddt, $J_{(\mathrm{H}-\mathrm{PM} 3)}=25.2 \mathrm{~Hz}, J_{(\mathrm{H}-\mathrm{PC} y)}=56.1 \mathrm{~Hz}, J_{(\mathrm{H}-}$ $\mathrm{PPh})=40.3 \mathrm{~Hz}$ ). The ${ }^{29} \mathrm{Si}\left\{{ }^{1} \mathrm{H}\right\}$ spectrum, recorded on the crude mixture revealed the formation of the known (bis-silyl)amine 8 which was quantified in ca $66 \%$ yield after extraction and hydrolysis to $\mathrm{NH}_{4}{ }^{+}$. Unfortunately, complex $\mathbf{7 - X}$ has resisted crystallization to date, and several derivatization experiments were carried out to finally ascertain its formulation.

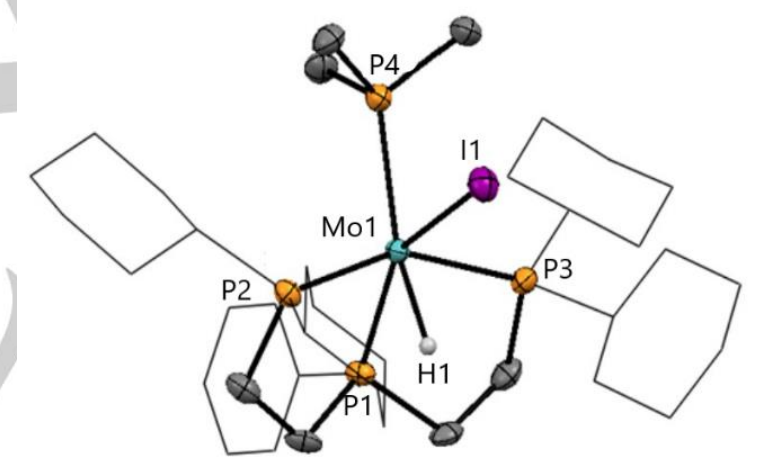

Figure 2. X-ray structure of complex 9: $50 \%$ thermal ellipsoids are shown Hydrogen atoms, except for the hydride, have been omitted for clarity. Selected bond lengths $[\AA \AA]$ and angles $\left[^{\circ}\right]$ : Mo1-P1 2.344(1), Mo1-P2 2.482(1), Mo1-P3 2.487(1), Mo1-P4 2.501(1), Mo1-I1 2.932(1), Mo1-H1 1.77(4); P1Mo1-P2 81.5(1), P1-Mo1-P3 81.7(1), P2-Mo1-P3 150.9(1), P1-Mo1-P4 137.7(1), P2-Mo1-P4 104.1(1), P3-Mo1-P4 104.5(1), P1-Mo1-I1 144.3(1) P2-Mo1-I1 90.3(1), P3-Mo1-I1 89.7(1), P4-Mo1-I1 77.9(1), P1-Mo1-H1 63.0(13), P2-Mo1-H1 75.0(13), P3-Mo1-H1 76.2(13), P4-Mo1-H1 159.3(13), I1-Mo1-H1 81.3(13)

First, complex 7-X was reacted with $\mathrm{I}^{-}$sources (Nal, $\mathrm{NBu}_{4}$ l) in order to form the corresponding $\mathrm{Mo}^{(\text {II) }}$ neutral complex. The reaction was surprisingly slow (ca 48h) and provided several complexes, likely isomers. Crystals were grown from the crude mixture, and X-ray diffraction analysis was carried out on complex 9, which structure is presented in Figure 2. It is an isomer of a (PPP) $\mathrm{Mo}(\mathrm{H})(\mathrm{I})\left(\mathrm{PMe}_{3}\right)$ complex reported by our group from the reaction between complex $\mathbf{1}$, bis-silane 2 (excess) and $\mathrm{PMe}_{3}{ }^{[29]}$

In a second experiment, complex 7-X was mixed with $\mathrm{H}_{2}$ in the presence of $\mathrm{PMe}_{3} .{ }^{1} \mathrm{H}$ and ${ }^{31} \mathrm{P}\left\{{ }^{1} \mathrm{H}\right\}$ NMR reaction monitoring 
indicated rather slow kinetics and ca $50 \%$ of the expected complex [(PPP)Mo(H) $\left.)_{3}\left(\mathrm{PMe}_{3}\right)_{2}\right]^{+} \mathbf{1 0}$ is formed after $12 \mathrm{~h}$. Nearly full conversion was achieved after 4 days at room temperature. Representative ${ }^{1} \mathrm{H}$ NMR spectra at different stages are presented in Figure 3.

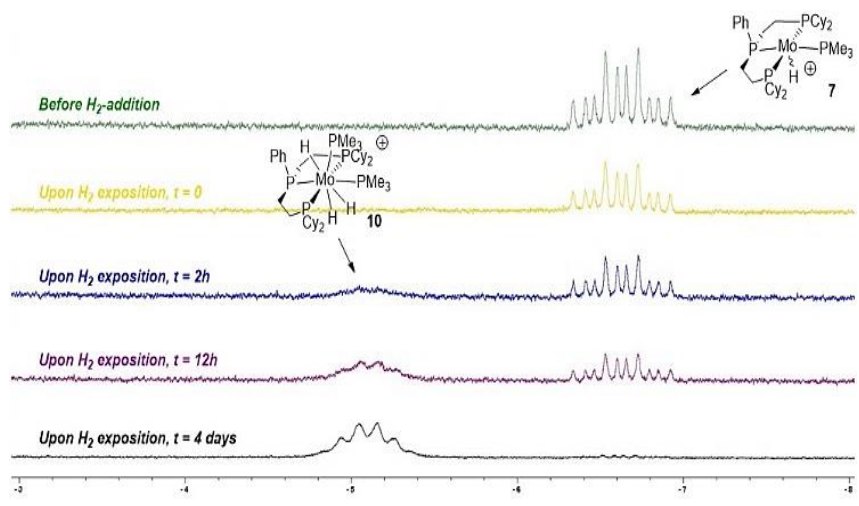

Figure 3. Hydride region of ${ }^{1} \mathrm{H}$ spectra of the reaction between complex $\mathbf{7 - X}$, $\mathrm{PMe}_{3}$ and $\mathrm{H}_{2}$ showing the formation of complex $10-\mathrm{X}$.

To gain insight into the mechanisms of the various transformations observed experimentally, DFT(PBE0-D3) calculations were carried out on the actual experimental systems (see ESI for computational details; geometries of all the optimized structures are available in a single file in xyz format).

The reactivity of the $\mathrm{Mo}^{(\mathrm{IV})}$ nitrido complex $\mathbf{A}$ with the bissilane $\mathrm{HMe}_{2} \mathrm{Si}-\left(\mathrm{CH}_{2}\right)_{2}-\mathrm{SiMe}_{2} \mathrm{H}$ was studied computationally (Scheme 4). The first $\mathrm{Si}-\mathrm{H}$ bond activation is effective through TS-A-E with an activation barrier of $\Delta \mathrm{G}^{\#}=31.9 \mathrm{kcal} \mathrm{mol}^{-1}$ with respect to A. In TS-A-B, the Mo-N bond lengthens $(1.685 \AA)$ and the $\mathrm{N} \cdots$ Si distance $(2.200 \AA)$ is relatively long. Concomitantly the hydrogen atom significantly interacts with the metal $(\mathrm{Mo} \cdots \mathrm{H}=$ $1.775 \AA$ ), while the $\mathrm{Si}-\mathrm{H}$ bond has lengthened to $1.754 \AA$ (1.502 $\AA$ in the free bis-silane). The Mo-imido hydride product $\mathbf{B}$ is computed to be less stable than $A$ by $\Delta \mathrm{G}=9.5 \mathrm{kcal} \mathrm{mol}^{-1}(\mathrm{~N}-\mathrm{Si}$ $=1.764 \AA, \mathrm{Mo}-\mathrm{N}=1.740 \AA$, and $\mathrm{Mo}-\mathrm{H}=1.704 \AA$ in $\mathrm{B}$ ). The isomer $\mathbf{C}$, where the respective positions of $\mathrm{H}$ and I have been swapped is computed to be significantly more stable than B by $\Delta \mathrm{G}=-14.5 \mathrm{kcal} \mathrm{mol}^{-1}$. The relative energy of $\mathbf{A}$ and $\mathbf{C}$ (Scheme 4 ) is in perfect agreement with the experimental observations of the formation of $\mathbf{3}$ (Scheme 2). However, the computed activation barrier for the formation of $\mathbf{B}$ is too high for a transformation complete in 4 hours at room temperature under stoichiometric conditions. At present, we suspect the involvement of a second $\mathrm{Si}-\mathrm{H}$ moiety to assist the $\mathrm{Si}-\mathrm{H}$ addition across the Mo-nitride bond via a more accessible transition state but have not yet found the corresponding pathway by calculations.

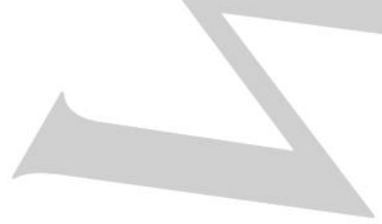

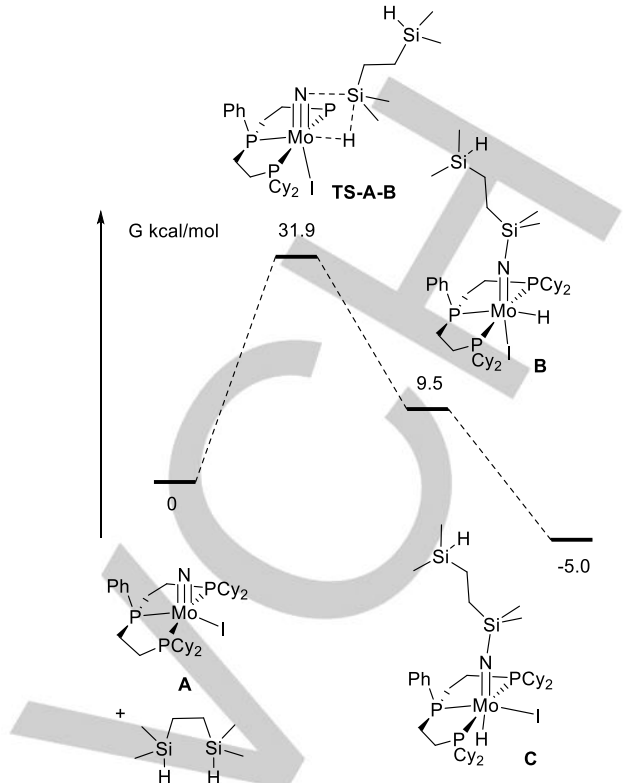

Scheme 4. Computed mechanism for the $\mathrm{Si}-\mathrm{H}$ bond activation on the neutral $\mathrm{Mo}^{(\mathrm{IV})}$ nitrido starting complex 1 . Gibbs free energies $\left(\mathrm{kcal}^{\mathrm{mol}}{ }^{-1}\right)$ are given relative to "A + bis-silane". Most $\mathrm{H}$ atoms have been omitted for clarity.

Experimentally, abstraction of the iodide results in an increased reactivity of the $\mathrm{Mo}^{(\mathrm{IV})}$ nitride complex (Scheme 2). Even though the formation of the cationic nitrido complex $\mathbf{D}$ is computed to be endoergic ( $\Delta \mathrm{G}=19.6 \mathrm{kcal} \mathrm{mol}^{-1}$ with respect to A), further precipitation of TIl will shift the equilibrium toward formation of $\mathbf{D}$. This cationic complex activates much more easily the $\mathrm{Si}-\mathrm{H}$ bond of the bis-silane with a computed activation barrier of $\Delta \mathrm{G}^{\#}=6.3 \mathrm{kcal} \mathrm{mol}{ }^{-1}$ for TS-D-E (Scheme 5). Inspection of selected geometrical parameters indicates that the TS is a late transition state compared to TS-A-B (Mo-N = 1.685 $\AA, \mathrm{Mo}-\mathrm{H}=1.775 \AA, \mathrm{N}-\mathrm{Si}=2.200 \AA \mathrm{S}, \mathrm{Si}-\mathrm{H}=1.754 \AA$ in TS-A-B $\mathrm{Mo}-\mathrm{N}=1.661 \AA$, Mo-H $=1.745 \AA$, N-Si $=2.178 \AA$, Si-H $=$ $1.947 \AA$ in TS-D-E). The reaction is strongly exoergic with $\Delta \mathrm{G}=$ $-17.2 \mathrm{kcal} \mathrm{mol}^{-1}$, whereas it was endoergic in the neutral case with iodide still coordinated to Mo. From this mono-activation intermediate, the second $\mathrm{Si}-\mathrm{H}$ bond activation process is effective through TS-E-F with an activation barrier of only $\Delta \mathbf{G}^{\#}=$ $11.4 \mathrm{kcal} \mathrm{mol}^{-1}$. The formation of the cationic amido-dihydride $\mathbf{F}$ is computed to be exoergic with $\Delta \mathrm{G}=-9.5 \mathrm{kcal} \mathrm{mol}^{-1}$ from $\mathbf{E}$.

The calculations are in perfect agreement with the experimental observations (Scheme 2). Abstraction of the iodide in $\mathbf{1}$ to form $6^{+}$opens up a pathway for very fast activation of the two $\mathrm{Si}-\mathrm{H}$ bonds in the bis-silane to form the dihydride $5^{+}$. lodide abstraction in $\mathbf{3}$ also leads to easy $\mathrm{Si}-\mathrm{H}$ bond activation to form the dihydride $\mathbf{5}^{+}$. In addition the transition state TS-F-G associated with the $\mathrm{N}-\mathrm{H}$ bond formation step delivering the (bissilyl)amine product $\mathbf{8}$ was located on the potential energy surface (Scheme 4). The activation barrier of $\Delta G^{\#}=29.6 \mathrm{kcal}$ $\mathrm{mol}^{-1}$ to form complex $\mathbf{G}$ is not only high but more importantly this transformation is computed to be endergonic by $\Delta \mathrm{G}=9.7$ $\mathrm{kcal} \mathrm{mol}^{-1}$. It is therefore in agreement with experimental results, which show that complex $\mathbf{5 - X}$ is the only observed complex. 


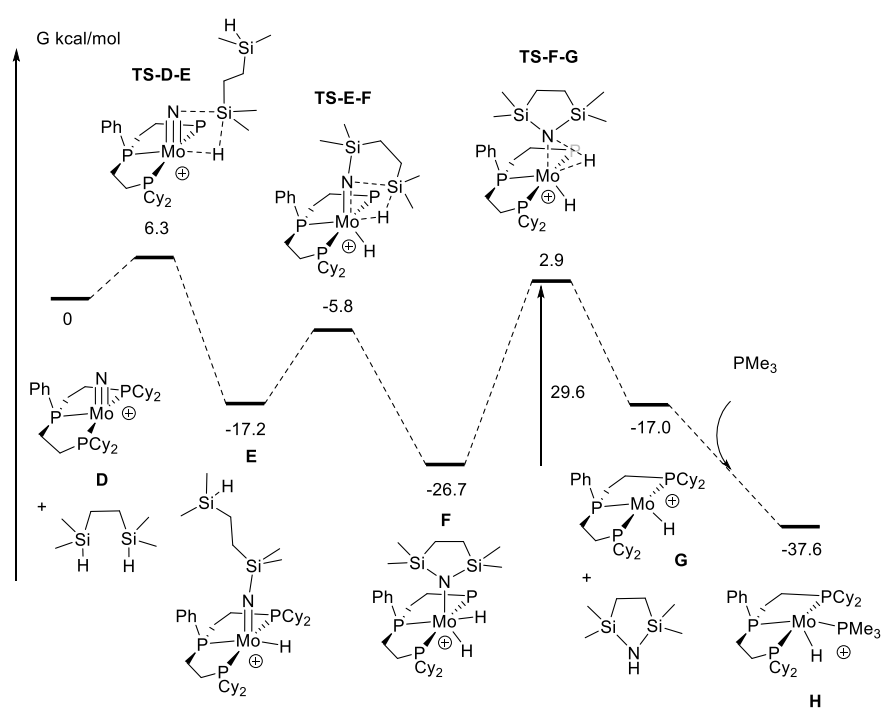

Scheme 5. Computed mechanism for the $\mathrm{Si}-\mathrm{H}$ bond activations on the cationic $\mathrm{Mo}^{(\mathrm{IV})}$ nitride complex. Gibbs free energies $\left(\mathrm{kcal} \mathrm{mol}^{-1}\right)$ are given relative to "D + bissilane". Most $\mathrm{H}$ atoms have been omitted for clarity.

The reactivity of complex $5-\mathrm{X}$ with an additional $\mathrm{PMe}_{3}$ was subsequently probed. Two cases were computed. First, coordination of $\mathrm{PMe}_{3}$ on complex $\mathbf{F}$ resulted in an increased barrier for amine elimination ( $>30 \mathrm{kcal} \mathrm{mol}^{-1}$ ), and is therefore not the path followed. Secondly, coordination of $\mathrm{PMe}_{3}$ to $\mathbf{G}$ to form $\mathbf{H}$ is stabilizing with $\Delta \mathrm{G}=-20.6 \mathrm{kcal} \mathrm{mol}^{-1}$, thus an overall $10.9 \mathrm{kcal} \mathrm{mol}^{-1}$ stabilization from complex $\mathbf{F}$, which does explain amine formation upon addition of phosphine (Scheme 3), although the calculated overall barrier of $29.6 \mathrm{kcal} \mathrm{mol}^{-1}$ is high for a reaction occurring at room temperature.

Finally, the reactivity of complex 7-X toward $\mathrm{H}_{2}$ in the presence of $\mathrm{PMe}_{3}$ was evaluated. Addition of $\mathrm{PMe}_{3}$ on complex $\mathbf{H}$ is favorable by $11.8 \mathrm{kcal} \mathrm{mol}^{-1}$ to form complex $\mathbf{I}$, and the transition state TS-H-I was located at $\Delta \mathrm{G}^{\#}=21.8 \mathrm{kcal} \mathrm{mol}^{-1}$. This is too low an activation barrier to be consistent with experimental observation (complex $\mathbf{7 - X}$ is stable in the presence of additional phosphine). We therefore considered the influence of triflate on the stability of complexes $\mathbf{H}$ and $\mathbf{I}$. Coordination of triflate trans to the $\mathrm{H}$ atom is evidenced in $\mathrm{H}-\mathrm{OTf}$, while complex I being saturated, I-OTf is optimized as an ion pair. The energy difference is now only $2.5 \mathrm{kcal} / \mathrm{mol}$ in favor of I-OTf, which indicates a $9.3 \mathrm{kcal} / \mathrm{mol}$ stabilization of unsaturated complex $\mathbf{H}$ by triflate coordination. Importantly, this translates into an additional energy cost to reach TS-H-I as OTf has to decoordinate prior to $\mathrm{PMe}_{3}$ coordination. .

The transition state for $\mathrm{H}_{2}$ addition to I, TS-I-J, was located on the potential energy surface at $\Delta \mathrm{G}^{\#}=17.0 \mathrm{kcal} \mathrm{mol}{ }^{-1}$ above I. The product of the $\mathrm{H}_{2}$ oxidative addition, $\mathbf{J}$, is computed to be more stable than I by $\Delta \mathrm{G}=-9.3 \mathrm{kcal} \mathrm{mol}^{-1}$, and thus $20.1 \mathrm{kcal}$ $\mathrm{mol}^{-1}$ lower than $\mathbf{H}$. The computed results are qualitatively in agreement with the experimental observations for the transformation $\mathbf{7} \rightarrow \mathbf{1 0}$ (Scheme 3), and the calculated values indicate a strongly exoergic transformation with coordination of the second phosphine following OTf decoordination more energy demanding than $\mathrm{H}_{2}$ oxidative addition.

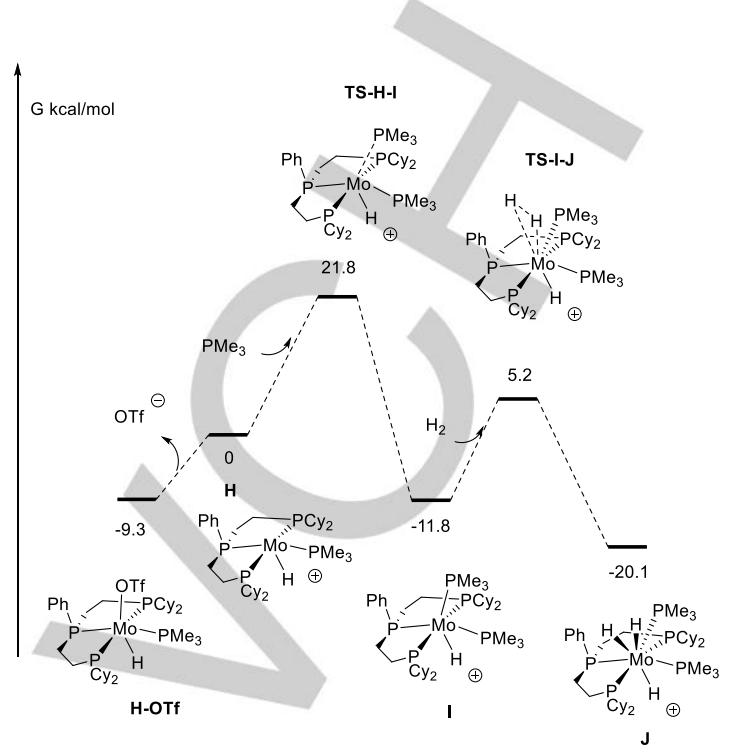

Scheme 6. Computed mechanism for $\mathrm{H}_{2}$ addition to complex $\mathbf{H}$ in the presence of $\mathrm{PMe}_{3}$. Gibbs free energies $\left(\mathrm{kcal} \mathrm{mol}^{-1}\right.$ ) are given relative to "H + $\mathrm{PMe}_{3}+\mathrm{H}_{2}$ ". Most $\mathrm{H}$ atoms have been omitted for clarity.

In conclusion, we have explored a new route of stepwise functionalization of a nitride complex to silylamine under mild conditions. We have shown that the liberation of a free coordination site on the imido complex 3 through halide abstraction facilates the second 1,2 addition of $\mathrm{Si}-\mathrm{H}$ on the Mo-N bond, affording the stable cationic (bis-hydride)-amide complex 5-X. Alternatively, complex $\mathbf{5 - X}$ can be obtained directly from the reaction of the cationic nitride complex $\mathbf{6 - X}$ and bissilane 2. This amido-bis-hydride complex is rather stable and reluctant to reductive elimination. However, the liberation of the silylamine was achieved at room temperature by addition of $\mathrm{PMe}_{3}$. DFT calculations rationalizing our experimental findings are presented.

\section{Acknowledgements}

Financial support from CNRS and Université de Toulouse is acknowledged. N.M. thanks the "Région Midi-Pyrénées" as well as the IDEX of the Université Fédérale Toulouse Midi-Pyrénées for generous funding. S.B. is grateful to the ANR-CaDeSMARE for a Ph.D fellowship. We thank Solvay for a generous gift of phosphines, and CalMip (CNRS,Toulouse, France) for calculation facilities.

CCDC-1966908 (4) and CCDC-1966909 (9) contain the supplementary crystallographic data for this paper. These data are provided free of charge by The Cambridge Crystallographic Data Centre.

Keywords: $\mathrm{N}_{2}$ reduction $\cdot$ Molybdenum $\cdot$ bis-silane $\cdot$ nitride functionalization $\cdot$ hydride ligands 
[1] A. E. Shilov, Russ. Chem. Bull. 2003, 52, 2555-2562.

[2] N. Gruber, J. N. Galloway, Nature 2008, 451, 293-296.

[3] J. N. Galloway, A. R. Townsend, J. W. Erisman, M. Bekunda, Z. Cai, J. R. Freney, L. A. Martinelli, S. P. Seitzinger, M. A. Sutton, Science 2008, 320, 889-892.

[4] D. E. Canfield, A. N. Glazer, P. G. Falkowski, Science 2010, 330, 192-196.

[5] M. D. Walter, in Adv. Organomet. Chem., Elsevier, 2016, pp. 261-377.

[6] Y. Nishibayashi, Transition Metal-Dinitrogen Complexes: Preparation and Reactivity, John Wiley \& Sons, 2019.

[7] O. Einsle, Science 2002, 297, 1696-1700.

[8] Y. Zhao, S.-M. Bian, H.-N. Zhou, J.-F. Huang, J. Integr. Plant Biol. 2006, 48, 745-755.

[9] B. M. Hoffman, D. Lukoyanov, D. R. Dean, L. C. Seefeldt, Acc. Chem. Res. 2013, 46, 587-595.

[10] D. V. Yandulov, R. R. Schrock, Science 2003, 301, 76-78.

[11] K. Arashiba, E. Kinoshita, S. Kuriyama, A. Eizawa, K. Nakajima, H. Tanaka, K. Yoshizawa, Y. Nishibayashi, J. Am. Chem. Soc. 2015, 137, 5666-5669.

[12] V. Smil, Enriching the Earth: Fritz Haber, Carl Bosch, and the Transformation of World Food Production, MIT, Cambridge, Mass. London, 2001.

[13] K. Honkala, A. Hellman, I. N. Remediakis, A. Logadottir, A. Carlsson, S. Dahl, C. H. Christensen, J. K. Nørskov, Science 2005, 307, 555558 .

[14] M. D. Fryzuk, B. L. Jason, J. R. Steven, Victor G. Young, Science 1997, 275, 1445-1447.

[15] J. R. Jenning, Catalytic Ammonia Synthesis: Fundamentals and Practice., Springer-Verlag New York, 2013.

[16] H.-P. Jia, E. A. Quadrelli, Chem Soc Rev 2014, 43, 547-564.

[17] K. Arashiba, A. Eizawa, H. Tanaka, K. Nakajima, K. Yoshizawa, Y Nishibayashi, Bull. Chem. Soc. Jpn. 2017, 90,1111-1118.

[18] G. A. Silantyev, M. Förster, B. Schluschaß, J. Abbenseth, C. Würtele C. Volkmann, M. C. Holthausen, S. Schneider, Angew. Chem. Int. Ed. 2017, 56, 5872-5876.

[19] T. J. Hebden, R. R. Schrock, M. K. Takase, P. Müller, Chem Commun. 2012, 48, 1851-1853.

[20] T. Shima, S. Hu, G. Luo, X. Kang, Y. Luo, Z. Hou, Science 2013, 340 1549-1552.

[21] Y. Ashida, K. Arashiba, K. Nakajima, Y. Nishibayashi, Nature 2019, 568, 536-540.

[22] L. A. Wickramasinghe, T. Ogawa, R. R. Schrock, P. Müller, J. Am. Chem. Soc. 2017, 139, 9132-9135.

[23] J. J. Curley, E. L. Sceats, C. C. Cummins, J. Am. Chem. Soc. 2006 , $128,14036-14037$.

[24] J. S. Figueroa, N. A. Piro, C. R. Clough, C. C. Cummins, J. Am. Chem Soc. 2006, 128, 940-950.

[25] C. E. Laplaza, C. C. Cummins, Science 1995, 268, 861-863.

[26] J. J. Curley, A. F. Cozzolino, C. C. Cummins, Dalton Trans. 2011, 40 2429-2432.

[27] I. Klopsch, M. Finger, C. Würtele, B. Milde, D. B. Werz, S. Schneider, J. Am. Chem. Soc. 2014, 136, 6881-6883.

[28] Q. Liao, N. Saffon-Merceron, N. Mézailles, ACS Catal. 2015, 5, 6902 6906.

[29] Q. Liao, A. Cavaillé, N. Saffon-Merceron, N. Mézailles, Angew. Chem Int. Ed. 2016, 55, 11212-11216.

[30] M. F. Espada, S. Bennaamane, Q. Liao, N. Saffon-Merceron, S Massou, E. Clot, N. Nebra, M. Fustier-Boutignon, N. Mézailles, Angew. Chem. Int. Ed. 2018, 57, 12865-12868.

[31] R. H. Morris, Coord. Chem. Rev. 2008, 252, 2381-2394.

[32] X.-L. Luo, J. A. K. Howard, R. H. Crabtree, Magn. Reson. Chem. 1991 29, S89-S93. 


\section{Article}

A Mo-Nitride complex is functionalized by a bis-silane to form the Mo-imide-hydride complex then the corresponding Mo-amidebishydride complex en route to the silylamine derivative. DFT calculations supporting the experimental findings are presented.

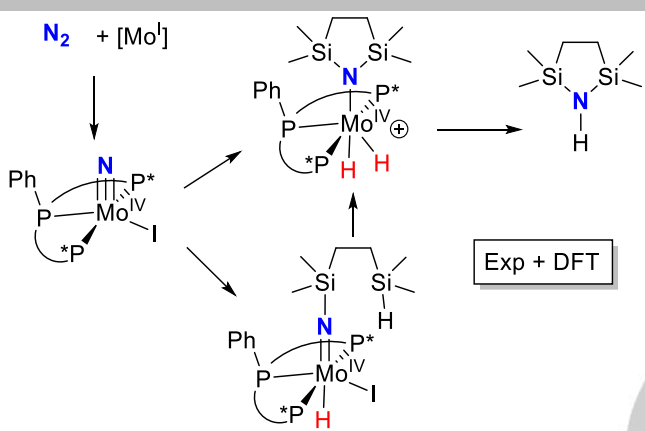

Soukaina Bennaamane, Maria F. Espada, Ikram Yagoub, Nathalie Saffon-Merceron, Noel Nebra, Marie Fustier-Boutignon, Eric Clot ${ }^{*}$ and Nicolas Mézailles *

Page No. - Page No.

Stepwise Functionalization of $\mathrm{N}_{2}$ at Mo: Nitrido to Imido to Amido. Factors Favoring Amine Elimination from the Amido Complex. 